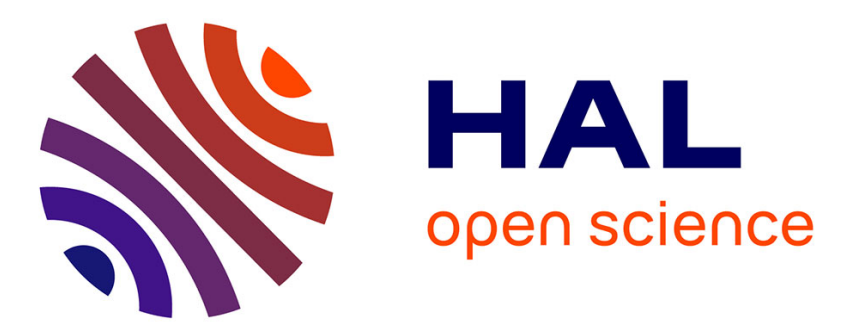

\title{
The cooperative works, a teacher training system open to the local social network
}

Jean-Jacques Salone

\section{To cite this version:}

Jean-Jacques Salone. The cooperative works, a teacher training system open to the local social network. ADVANCES IN THE ANTHROPOLOGICAL THEORY OF THE DIDACTIC AND THEIR CONSEQUENCES IN CURRICULA AND IN TEACHER EDUCATION, Jun 2019, Barcelona, Spain. hal-02733801

\section{HAL Id: hal-02733801 \\ https://hal.science/hal-02733801}

Submitted on 2 Jun 2020

HAL is a multi-disciplinary open access archive for the deposit and dissemination of scientific research documents, whether they are published or not. The documents may come from teaching and research institutions in France or abroad, or from public or private research centers.
L'archive ouverte pluridisciplinaire HAL, est destinée au dépôt et à la diffusion de documents scientifiques de niveau recherche, publiés ou non, émanant des établissements d'enseignement et de recherche français ou étrangers, des laboratoires publics ou privés. 


\section{The cooperative works, a teacher training system open to the local social network}

$\underline{\text { Salone Jean-Jacques }}$

Centre Universitaire de Formation et de Recherche de Mayotte, France; jean-jacques.salone@univ$\underline{\text { mayotte.fr }}$

Since September 2017 an initial training curriculum at master's level is set up for primary school teachers in Mayotte, a French department in the southern hemisphere. It is based on a specific training system, the cooperative works, which favors the improvement of professional skills and more specifically a competence of contextualization. In this paper we describe this training system with concepts from the anthropological theory of didactics such as the Herbartian schema and we expose research results about how it allows the questioning of the Mahoran heritage and society.

Keywords: Cooperative works, master MEEF, questioning the world, Mayotte, primary school teachers.

\section{Introduction}

For Mayotte, a French island since 1843 and department since 2011, the professionalization of teachers is an important issue. One reason is that the School of the Republic in Mayotte educates a growing number of pupils, with a school population exceeding the symbolic hurdle of 100,000 students in 2018-2019 (Vice-Rectorat of Mayotte, 2018, p. 2). It is in this social context that since September 2017, the Centre Universitaire de Formation et de Recherche (CUFR) of Mayotte, in partnership with the Vice-Rectorat of Mayotte, the University of La Reunion and the Ecole Supérieure du Professorat et de l'Education of La Reunion, has offered an initial training curriculum at master level for Primary School Teachers.

Beyond the context of higher education, Mayotte also presents a particular socio-cultural context. In the first place, the schooling language, French, is not the native language of the island. As established by Laroussi (2009), it coexists with two other vehicular languages: Shimaore, a Bantu language, belonging to the Swahili area and Kibushi, a Malagasy variety of the Malayo-Polynesian family, the only one spoken outside of Madagascar. This linguistic difference is driven forward on a more generally cultural level, with a heritage that has its roots in the East African space. Furthermore, Blanchy-Dorel (1990) describes a society in which:

the worldview conveyed by the culture of Mayotte to its members is essentially a Muslim vision; but in most social circles, it is a popularized Islam that is mixed with non-Muslim elements coming as much from the pre-Islamic Arab animist traditions as from African (Bantu) traditions. (Blanchy-Dorel, 199“0, p. 112)

In particular, in the village where he is raised, the young child goes to the Koranic school" (Blanchy-Dorel, 1990, p. 55).

One of the peculiarities of Mayotte also lies in its natural insular and tropical heritage. "Mayotte has been identified internationally as part of the 238 Ecoregions of the World Fund by nature, high places of biodiversity" (Amann, Amann, Arhel, Guiot and Marquet, 2008, p. 30). 
But this heritage, cultural or natural, is strongly threatened. Its preservation has become a major issue, and school is no exception. The project put forward for primary and secondary schools suggests "developing the concept of living well together: Recognizing cultural otherness and making civilization by coexisting in different cultures and languages" (Vice-Rectorat of Mayotte, 2016, p. 1).

In the present paper we describe the training system in terms from the Anthropological Theory of Didactics (ATD) and we report global results on how it enforces the students' abilities in questioning the world.

\section{Theoretical framework}

Our focus in the graduate master courses we propose is thus placed on the competence of contextualization, the "ability to integrate different contextual spheres which partly drives the nature of the processes at work in the management of this professional situation of teaching" (Sauvage-Luntadi \& Tupin, 2012, p. 106). According to Raynaud (2005), we will not try to differentiate the notion of context from those of environment or situation. We prefer to adopt a systemic approach: "rather than causally depending or referring action to "context" or "environment", we can consider that the individual accesses information through the arcs of his social network" (Raynaud 2005, p. 17).

According to ATD (Chevallard, 1985/1991; Chevallard, 2007; Bosch and Gascon, 2006; Winslow, 2011), intentional human activity is always motivated by tasks whose achievements relies on individual or institutional knowledge. These pieces of knowledge, called praxeologies, are constituted by techniques in order to accomplish some types of tasks (the practice block) and by discourses (the logos block) which explain techniques, the technologies, or justify them, the theories. Thus institutions (a person or a socially legitimated group) have their own praxeological equipment. Within a didactic systems $S$ based on didactic relations, some of these institutions $Y$, teachers for examples, have some other institutions $X$, the students, to improve their praxeological equipements. Then professional and/or disciplinary questions $Q$ are studied and collective praxeological answers $A^{\vee}$ are provided with the help of a milieu $M$. This milieu consists in partial answers $A \diamond$ stamped by some referent institution $\downarrow$, among which we find at least students and teachers themselves, and other objects $O$ (other resources for example) and derived questions $Q^{\prime}$. The following Herbartian schema summarizes this teaching/learning process:

$$
\left[S(X ; Y ; Q) \rightarrow M=\left\{A \diamond, O, Q^{\prime}\right\}\right] \leadsto A^{\bullet}
$$

In ATD didactic systems are not closed systems. They are imbedded in social networks which condition and constraint their underlying disciplinary and didactic organizations. At least four codeterminacy levels are identified outside classrooms: the pedagogy, which states teaching principles applying to all didactic systems independently from disciplines, the school with its internal capabilities to design and support teaching systems, the society, with its laws, rules or programs, and the civilization, an upper level beyond societies including for example cultural norms and traditions. Didactic systems then appear as open systems at the very core of macro-systems which overlap partially the non ATD concept of context: in each of those upper co-determinacy levels, many a priori a-didactic institutions can be found which all have praxeological equipment and thus which all may become referent institutions. Within this frame, the competence of contextualization 
may be seen as a professional teaching praxeology aiming at managing the flows of praxeological resources $A \diamond$ or $O$ from the available referent institutions $\diamond$ into the milieu $M$.

In Salone (2015), three types of these praxeological flows are highlighted, all of them spreading through specific social networks : scholar flows, in which scholar knowledge is subject to external and internal didactic transpositions (Chevallard, 1985/1991), private flows corresponding to private networks such as students' and teachers' ones, and more general social flows involving others referent institutions whose praxeological equipment are available directly in the nearby or indirectly through websites. These three contextual sub-systems allow teachers to make openings in their classes: activations of systemic relationships in order to influence the didactic systems. Three dimensions are underlined for these class openings: enrichment of the bodies of knowledge to which the class refers, diversification of the roles and topos of actors, widening of the didactic milieu. "In each of these three dimensions, openings can be performed not only internally, in the classroom, but also externally, by integrating non-didactical institutions" (Salone, 2015, p. 332).

Our analyses in this paper adopt this systemic approach with a focus on the society co-determinacy level. More precisely, we will look at the openings allowed by the training system we have designed for Primary School Teachers-in-training (PST) with a main issue: what are the praxeological, social flows between the didactic systems PST are involved in and the Mahoran society?

\section{Description of the cooperative works training system}

PST are actually involved in a specific training system: the cooperative works. Its goal is to equip them with professional praxeologies that will enable them to design courses that are both multidisciplinary and contextualized and that abandon the paradigm of visiting works to enter into that of questioning the world. In the cooperative works system, the whole group $X$ of PST is at first part of classical, didactic systems $S$ where it has lectures or helps from the teachers' trainers $Y$. Some generic questions $Q$ are then asked, such as what is to be done and how, and answers $A^{\bullet}$ are usually produced with the help of some visited theoretical works $W \diamond$. The Herbartian schema in these phases is:

$$
[S(X ; Y ; Q) \rightarrow M=\{W \diamond\}] \leadsto A^{\bullet}
$$

PST also freely constitute groups of 3 to 5 people in order to enter a project, the cooperative works stricto sensu, which includes: a contextualized and multidisciplinary inquiry during the first semester, a didactic work and an educational booklet during the second semester and, in semesters 3 and 4 of the second year, teaching sequences for their classes. The results we present in the next section concern exclusively inquiries and didactic works conducted in 2017-2018. In ATD terms, each PST group enter a two years Study and Research Path (SRP) with a generating question $Q_{0}$ which could be: how can we (our group) design multidisciplinary teaching situations relying on thematic resources about Mayotte's heritage?

The contextualized and multidisciplinary inquiry is a training and teaching technology related to the inquiry-based learning pedagogy (Dewey, 1993) and to a documentary work (Gueudet and Trouche, 2010). It articulates two main types of questions: $Q_{1}$ : what is known about the theme we have chosen in Mayotte's heritage or society; $Q_{2}$ : which multidisciplinary bodies of academic knowledge could be related to the theme? The inquiry also looks for possible places that can serve as school fieldtrips and for available resource persons, citizens' associations or institutional partners 
(derived questions $Q^{\prime}$ ). When inquiring, the PST group $G_{i}$ meet local actors $Y_{L}$ who provides some resources $A^{L}$ and who sometimes contribute to their works. It also collects resources $O$ from the available media such books or Internet. Each multidisciplinary survey then leads to a corpus of digital documents $C^{i}$. The herbartian schema in these inquiries is:

$$
\left[S\left(G_{i} ; Y_{L} ; Q_{1}, Q_{2}\right) \rightarrow M=\left\{A^{L}, O, Q^{\prime}\right\}\right] \rightarrow C^{i}
$$

In the second semester, the creation of a didactic work $W^{i}$ is part of an educational approach similar to that of the "masterpieces" in the sense of Freinet (1994) or Meirieu (2015): trainees have to produce by their own a terminal work, a masterpiece, to show their professional skills and abilities. Theses masterpieces must of course be related to the previous inquiry theme and they always include an aesthetic dimension that here relies mainly on digital and artistic skills. As professional productions, they integrate also a pedagogical intention directed for a general or school-related audience, with for example the transmission of a knowledge or a message to bring awareness to a certain topic. The question for the PST group is then $Q_{3}$ : what knowledge do we want to transmit? And the herbartian schema is:

$$
\left[S\left(G_{i} ; \text { empty; } Q_{3}\right) \rightarrow M=\left\{C^{i}\right\}\right] \leadsto W^{i}
$$

After a five months production process, books, youth albums, slideshows or documentary movies are thus created. They are thereafter publicly presented and are evaluated by a jury composed of teachers' trainers, researchers and institutional partners. Finally, the best didactic works are published and disseminated in society, at least in schools, to become teaching resources.

In the context of some disciplinary teaching units such as French or Mathematics, the cooperative groups also produce an educational booklet whose purpose is to propose ways of using in classes the resources thus constituted, inquiry materials and didactic works. Hence these booklets generally contain examples of contextualized disciplinary organizations, with for example activities, problems or exercises statements. In the second year of the master curriculum, when every two weeks PST have their own classes, this transposition process of thematic resources into scholar ones is continued.

\section{Methodological framework}

In this paper we present results upon the cooperative works realized during the academic year 2017-2018. Thirty cooperative groups were formed this year. Some of their cooperatives works may be downloaded on our website (http://www.univ-mayotte.fr/fr/formation/sciences-de-1-education/ travaux-des-etudiants.html) and three of them are also described in Salone (2019).

In order to answer our research question about the praxeological, social flows induced by the cooperative works training system, we examine in this paper the data coming directly from the contextualized and multidisciplinary inquiries along with the produced didactic works. Three derived questions are answered: what are the themes chosen par the PST? What academic disciplines did they involved? Which socio-economic actors have they met? Indicators are therefore used. For the first question, the indicator is the topic which appears in the titles of the didactic works. We use there a four types categorization derived from Hartog (2005): natural heritage, tangible cultural heritage, intangible cultural heritage and societal issues. Mixed themes belonging to several categories will be admitted. For the second question, the investigated school disciplines are directly identified in the documents from the inquiries bodies. For the third question, the 
encountered local actors that we retain are those who are cited or referenced in both the inquiries and the didactic works and we categorize them within three types: institutions, citizens' associations and referent persons.

\section{Results}

The chosen contextualized themes are varied. In Figure 1, we can see a cloud of the first-page photographs of the documents gathering the data from the inquiries. Mostly, with 23 works out of 30 , they fall under a theme related to intangible cultural heritage, such as traditional games (for example the local awale type sowing game called 'mraha wa tso'), cooking recipes (for example the 'mataba', a typical course from south and central Africa made from mashed cassava leaves), arts and crafts (the countless braiding and uses of coconut leaves for example), lore (the 'msindzano' for example, a yellow, facial mask made of crushed coral, white clay and turmeric used by women) and crafts (such as the manufacturing process of the famous 'laka', the local canoe). 12 themes concern elements of the natural heritage, such as natural protected areas (for example the very known lagoon of Mayotte, or the volcanic lake 'Ziani') or endemic plant species (such as the always green oranges of Mtsamboro village) and 6 deal with societal issues (such as the sorting of waste, the preservation of the coral reef or the tire recycling in wall constructions). 2 themes concern the material cultural heritage (the 'banga', traditional tiny huts made of bamboo and clay, and sugar factories, ruined remains of the island's post-colonial industries, and the maritime transport by barge between the two main islands of Mayotte). Note that many of these themes are of course mixed (for example the 'Ziani' lake is at first a piece of Mayotte's natural heritage, but it is also a place at the very core of many legends and a highly popular tourist site) and that some themes have been addressed by several groups (such as 'msindzano' theme which has been investigated by 3 groups).

With regard to the multidisciplinary, each cooperative group has clearly identified many links between its theme and almost all the academic disciplines. Coming first, Mathematics and French have been investigated by all groups. In Mathematics, 27 groups have retained pieces of knowledge from the geometry domain or from the size and measurement domain which are present in the official programs of cycles 2 and 3 of elementary school (children approximately aged from 6 to 11). In French, all the groups have considered that fluency in written or spoken language can be improved by introducing local texts into the classroom, such as stories, songs, press articles or documents produced by citizens' associations. Visual arts, History, Geography and Moral and civic education are then the next most investigated disciplines. Their scores are respectively 22 groups (out of 30), 17, 16 and 16. Then came Science and technology, Natural sciences, Sport and Music.

The local actors met by the PST and sometimes involved in the cooperative works are numerous, with an average of 5 per group including at least one institutional partner. For example, about $80 \%$ of the groups have encountered the staff or the departmental archives of Mayotte and about $60 \%$ the team of the MuMa, Mayotte's museum. Among the citizens' associations, two have often been involved: the Mahoran naturalist, an association dealing with environmental and cultural issues, and SHIME, an association of local sociolinguists. Many referent persons in Mayotte, called 'fundi', have also been met. All these partners have been involved in several ways: to provide documentary resources, to answer questionnaires or to participate in interviews, to contribute to the designing of the didactic works. More than fifty institutional, associative or private partners were thus involved 
by the promotion witch thus woven a real educational network between the CUFR and the Mayotte society.

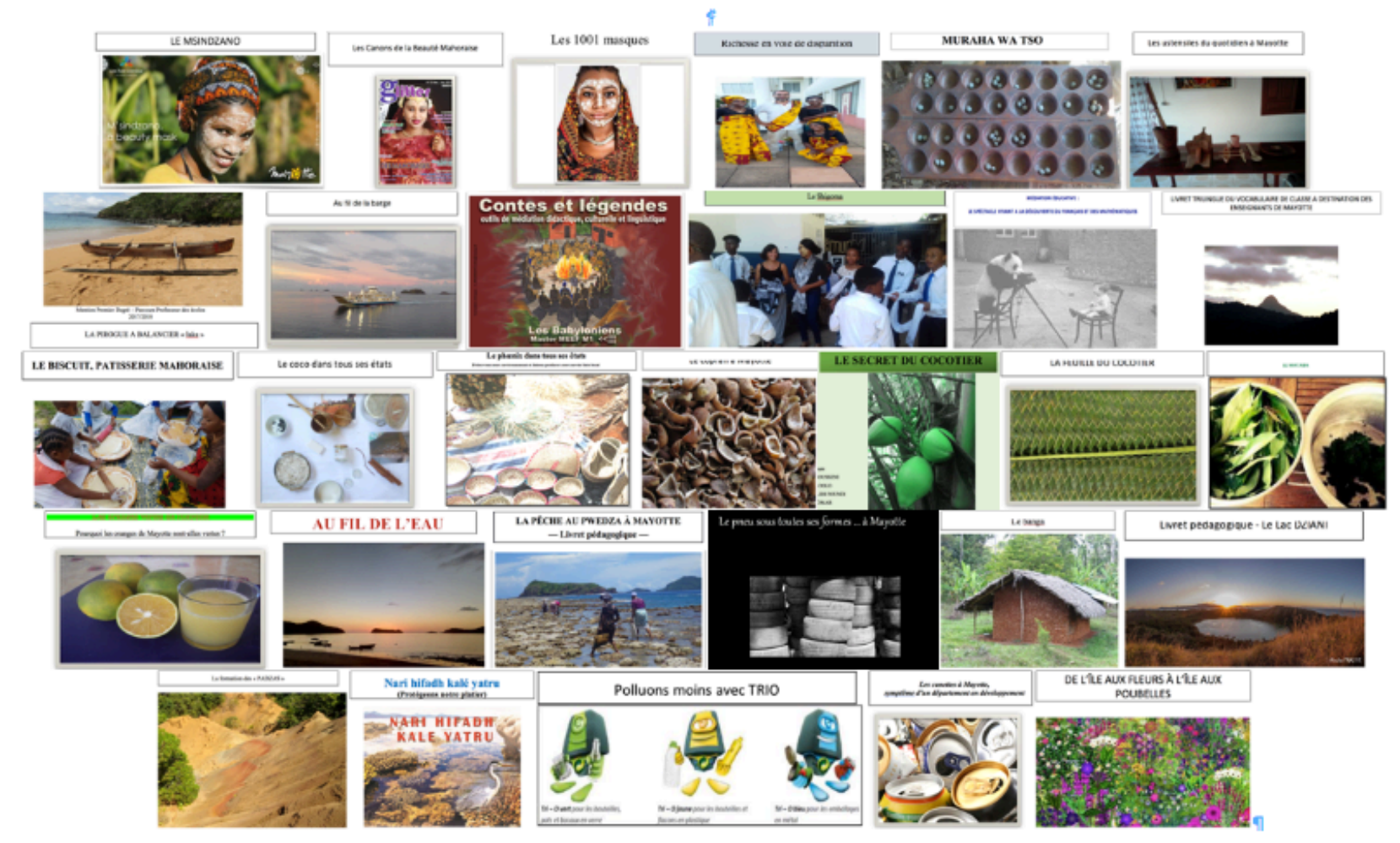

Figure 1: Cloud of selected themes

\section{Conclusion and perspectives}

The cooperative works system allows trainee teachers of schools who are engaged in our master curriculum to both strengthen their professional, praxeological equipement and acquire a good knowledge about Mayotte's heritage and society. First of all, through inquiries and systemic openings on the local social networks it fosters the emergence of contextualization skills. It also reinforces professional abilities in active pedagogies and it improves the mastery disciplinary knowledge. Moreover, for most of the PST, questioning the local world in order to create and organize educational activities in their classes has become something possible. Another gain induced by the cooperative works system is the large amount of produced materials: the didactic works (and also the educational booklets) are disseminated in Mayotte to become teaching resources and material coming from the inquiries are shared by researchers and institutional partners.

In terms of research, our team has recently been exploring additional issues about the cooperative works training system. For example, as the vehicular languages are an important part of the cultural heritage, the questions of their place in the didactic works and their uses in classroom are studied. More specifically, questions about the mathematical terms and idioms in these languages and their effects on the concepts formation arise. According to an ethnomathematical approach, other questions are coming to the shore such as the reinvestment in classes of traditional technologies or the use of handicraft artefacts. In a more sociological or ethnological approach, a main research 
issue also emerges: how, once tenured, will the PST involved in the cooperative works contribute to the development of Mayotte's education system?

\section{References}

Amann C., Amann G., Arhel R., Guiot V. \& Marquet G., (2008). Plantes de Mayotte. Tsingoni, Mayotte (France): Armen factory.

Blanchy-Dorel, S. (1990). La vie quotidienne à Mayotte. Paris (France): L'Harmattan.

Bosch, M., \& Gascón, J. (2006). Twenty-five years of the didactic transposition. ICMI bulletin, 58, pp. 51-65.

Chevallard, Y. (1985/1991). La transposition didactique, du savoir savant au savoir enseigné. Grenoble (France): La Pensée Sauvage.

Chevallard, Y. (2007). Passé et présent de la théorie anthropologique du didactique. Sociedad, escuela y matemáticas. Aportaciones de la Teoría Antropológica de lo Didáctico, pp. 705-746.

Dewey, J. (1993). Logique : la théorie de l'enquête. Paris (France): Presses universitaires de France.

Freinet, C. (1994). Les invariants pédagogiques. In CEuvres pédagogiques, 2. Paris (France): Seuil.

Gueudet, G. \& Trouche, L. (2010). Ressources vive : Le travail documentaire des professeurs en mathématiques. Rennes (France): Presses Universitaires de Rennes, INRP.

Hartog, F. (2005). Temps et patrimoine. Museum International, 57 (3), pp. 7-18.

Laroussi, F. (2009). Mayotte, une île plurilingue en mutation. Mamoudzou, Mayotte (France): Editions du Baobab.

Raynaud, D. (2005). Le contexte est-il un concept légitime de l'explication sociologique ? L'Explication sociologique. Quels sont les niveaux d'abstraction légitimes ? Communication at the colloquium organized by P. Demeulenaere, Nancy (France).

Salone, J-J. (2015). Les références praxéologiques dans les systèmes didactiques ( $\mathrm{PhD}$ Thesis). AixMarseille Université, Marseille (France). 〈tel-01164449>.

Salone, J-J. (2019). La contextualisation, une compétence professionnelle au centre du master Meef 1er degré de Mayotte. In Pelletier, L. \& Thomazet, S. (Eds.), La nouvelle revue - éducation et société inclusives, vol. 85, pp. 221-244.

Sauvage-Luntadi, L. \& Tupin, F. (2012). La compétence de contextualisation au coeur de la situation d'enseignement- apprentissage. Phronesis 11, pp. 102-117.

Vice-Rectorat of Mayotte. (2016). Projet académique 2016-2019. Retrieved from www.acmayotte.fr/images/docs/PA_plaquette_web.pdf

Vice-Rectorat of Mayotte. (2018, unpublished). Diaporama du Conseil de l'Education Nationale de Mayotte du 31 octobre 2018. Mamoudzou, Mayotte (France).

Winslow, C. (2011). Anthopological theory of didactic phenomena : Some examples and principles of its use in the study of mathematics education. In Bosch, M., Gascón, J., Ruiz Olarría, A., Artaud, M., Bronner, A., Chevallard, Y., Cirade, G., Ladage, C. \& Larguier, M. (Eds.), Un panorama de la TAD, pp. 117-138. 